\title{
Studies on the antibacterial and antioxidant activities of Sonchus asper (L.) Hill and Seseli diffusum (Roxb. ex Sm.) Sant. \& Wagh
}

\author{
${ }^{1}$ Priyadarsinee Mallik, ${ }^{2}$ Sagar Kumar Mishra, ${ }^{1}$ Kunja Bihari Satapathy \\ ${ }^{I}$ P.G. Department of Botany, Utkal University, Vani Vihar, Bhubaneswar -751004, Odisha, India \\ ${ }^{2}$ University Department of Pharmaceutical sciences, Utkal University, Vani Vihar,
} Bhubaneswar-751004, Odisha, India

\begin{abstract}
Antioxidant and antimicrobial properties of various extracts from plants have recently been of great interest in both pharmaceutics and food industries, because of their possible use as natural additives which emerged from a growing tendency to replace synthetic antioxidants with natural ones. Sonchus asper (L.) Hill, and Seseli diffusum (Roxb. ex Sm.) Sant. \& Wagh, were selected for the evaluation of their antibacterial and antioxidant activities against different disease-causing microorganisms such as Shigella flexneri, Micrococcus $s p$, Escherichia coli, and Staphylococcus aureus. The methanolic extract of Sonchus asper demonstrated more inhibitory activity against Staphylococcus aureus as compared to other plant extracts and pathogens where as the n-hexane extract of Sseseli diffusum exhibited highest antioxidant activity. The TLC study indicated that the n-hexane extract of Seseli diffusum resuted in more number of spots as compared to other solvents.
\end{abstract}

Key Words: Antibacterialal, Antioxidant, Seseli diffusum, Sonchus asper

\section{Introduction}

India is a varietal emporium of medicinal plants and it is one of the richest countries in the world in genetic resources of medicinal plants. Presently majority of people are relying on traditional medicines for their primary healthcare. Numerous studies have shown that aromatic and medicinal plants are rich sources of bioactive constituents, many of which display antimicrobial and antioxidant properties and have a major role in both cellular oxidation and against pathogens. Thus, it is essential to characterize different types of medicinal plants for their antioxidant and antimicrobial potential ${ }^{[1][2][3]}$. It was estimated by World Health Organization that $80 \%$ of the population of developing countries still rely upon traditional medicines, mostly plant-based drugs, for their primary healthcare needs.

The present work was carried out with an objective to focus and evaluate the in vitro antioxidant and antibacterial activities of different extracts of two promising medicinal plant species such as Sonchus asper (L.) Hill and Seseli diffusum (Roxb. ex Sm.) Sant. \& Wagh. The plant Sonchus asper belonging to family Asteraceae is an annual herb, and the tap root is usually unbranched ${ }^{[4]}$. This plant is having various potential bioactive chemical constituents ${ }^{[5]}$. S. asper is used in various human disorder including wounds, burns, gastrointestinal infection, inflammation, and cardiac dysfunction ${ }^{[6]}$; Kidney and liver disorder along with impotency in humans $^{[7]}$; Jundice ${ }^{[8]}$ and cancer ${ }^{[9][10]}$. Seseli diffusum, belonging to family Apiaceae is a diffused annual herb having folklore claims as antispasmodic and antidiuretic. Besides this both plants have ethnic claims on effective use for the treatment of many diseases including skin diseases, wounds, cold, cough, indigestion, diarrhoea, dyspepsia and boils etc.

In the present study, four disease causing bacteria such as Micrococcus sp., Escherichia coli, Staphylococcus aureus and Shigella flexneri were used as test organisms and the efficacy of two plant materials were investigated against the pathogens.

\subsection{Collection and processing of Plant Materials}

\section{Material And Methods}

The plant materials were collected from Chandaka reserve forest area, near Bhubanewar in Odisha and their local uses were recorded. The plant specimens were identified following available literature "Flora of Orissa" ${ }^{,[1]}$ and the voucher specimens were preserved and deposited in the Herbarium of Post Graduate Department of Botany, Utkal University, Bhubaneswar.

\subsection{Extraction of Plant Material}

The plants were washed with tap water, dried under shade and were made into coarse powder by grinding. The powdered plant materials were extracted successively with solvents such as n-Hexane, Chloroform and Methanol in Soxhelt apparatus for 48 hours. The extracts were concentrated by distillation in reduced pressure and kept in dessicator. 


\subsection{TLC profiling}

The extracts were subjected to Thin Layer Chromatography analysis by using different solvent system. The chromatogram on TLC plates were sprayed with sulfuric acid : methanol (5:95) reagent, dried and spots were observed and $\mathrm{Rf}$ value was calculated.

\subsection{In vitro antioxidant activity}

The in vitro antioxidant activity of extracts was conducted by DPPH radical scavenging assay. For this, $5 \mathrm{mg}$ extraction in $10 \mathrm{ml}$ of methanol was prepared and $1 \mathrm{ml}$ of this solution was added to $9 \mathrm{ml}$ of methanol. Then $1.5 \mathrm{ml}$ of solution from the above was added to $1.5 \mathrm{ml}$ of DPPH. This was kept in dark for 20 minutes and then absorbance was measured at $517 \mathrm{~nm}$. A blank was prepared without adding the extract. Ascorbic acid at various concentrations was used as standard. The lower absorbance of the reaction mixture indicates higher free radical scavenging activity. The capability to scavenge the DPPH radical was calculated using the following equation and the result was recorded (Table 2).

$$
\text { DPPH Scavenged }=\text { A Control }- \text { A test X } 100
$$

\subsection{In vitro antibacterial activity}

The extracts were screened for their antimicrobial activity against the bacteria Micrococcus sp., Staphylococcus aureus, Shigelia flexneri and Escherichia coli by agar-well diffusion method (Atta ur Rahman, 1991). The strains of bacteria were inoculated in different test tubes containing $10 \mathrm{ml}$ of nutrient broth. The test tubes were incubated at $37{ }^{\circ} \mathrm{C}$ for 24 hours. The extracts were dissolved in DMSO to make solution at a concentration of $6 \mathrm{mg} / \mathrm{ml}$ and further dilutions were prepared at the concentration of $3 \mathrm{mg} / \mathrm{ml}, 1.5 \mathrm{mg} / \mathrm{ml}$ and $0.75 \mathrm{mg} / \mathrm{ml}$. The agar plates were prepared and each bacterium was swabbed on the agar plate. The wells were dug on agar plates with the sterile cork borer of $8 \mathrm{~mm}$ diameter. $45 \mu \mathrm{l}$ of each dilution of extract was poured in respective well and the plates were incubated at $37^{\circ} \mathrm{C}$ for $24 \mathrm{hrs}$. The zone of inhibitions shown were measured in millimeter $(\mathrm{mm})$ and data were recorded.

\subsection{TLC profiling}

\section{Result and Discussion}

The n-hexane extracts of both plants were having Rf value of 0.50, 0.49 for Sonchus asper and 0.72, 0.82, 0.57, 0.62, 0.67 for Seseli diffusum and thus a number of spots were found on the TLC plate against different solvent system. It was noticed that the n-hexane extract of Seseli diffusum showed more number of spots than methanolic and chloroform extract of the same plant and also than that of Sonchus asper. This finding suggested that further separation of phyto-constituents can be carried out using n-hexane solvent system, since it indicated better separation in this solvent system (Table 1).

\subsection{Antioxidant activity}

The result of antioxidant activity of the extracts revealed that the n-hexane extract of Seseli diffusum showed highest antioxidant activity as compared to other extracts (Table 2).

\subsection{Antibacterial activity}

The bactericidal effect of the plant extracts were investigated in the form of inhibition zone against different pathogens. The results of antibacterial activity of the two plants showed that the methanolic extract of Sonchus asper had more potential to inhibit bacterial growth (Table $3 \& 4$ ).

Table 1: The TLC chromatogram of Sonchus asper and Seseli diffusum against different extracts

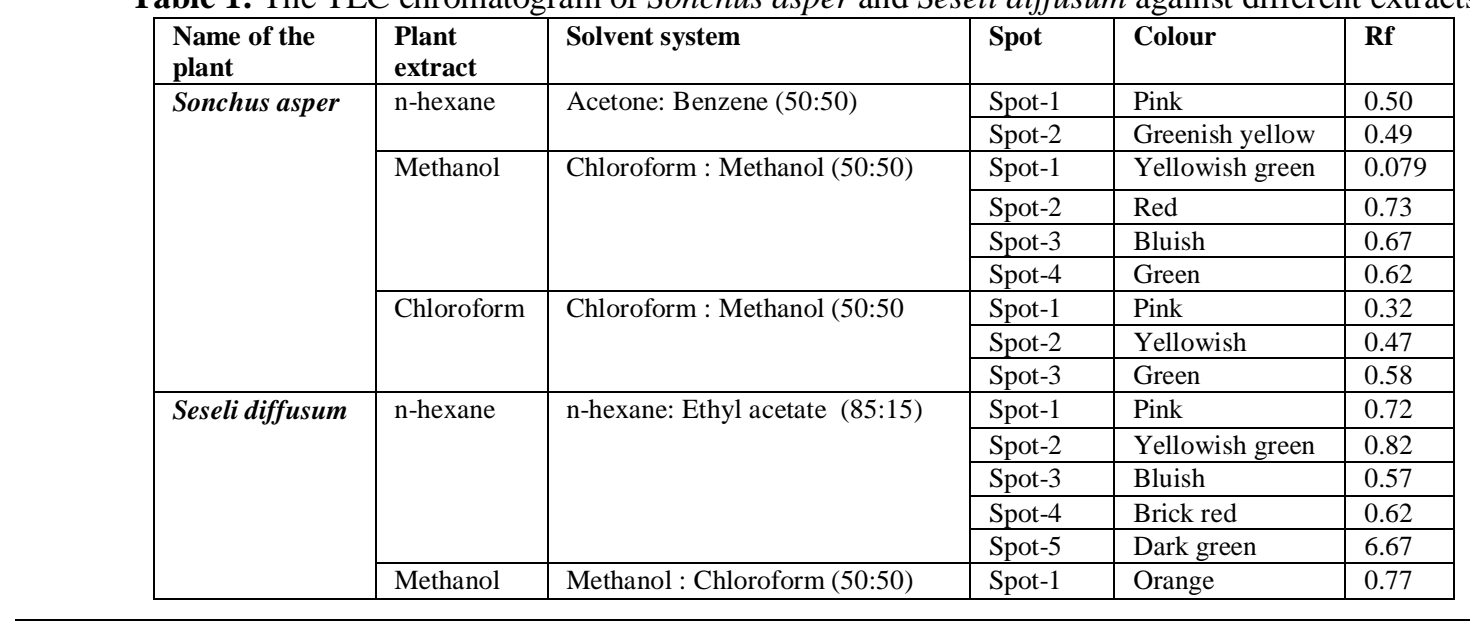


Studies on the antimicrobial and antioxidant activities of sonchus asper ...

\begin{tabular}{|l|l|l|l|l|l|}
\hline & & & Spot-2 & Greenish yellow & 0.90 \\
\cline { 3 - 6 } & & & Spot-3 & Brick red & 0.87 \\
\cline { 3 - 6 } & Chlorofom & Methanol : Chloroform (50:50) & Spot-1 & Green & 0.84 \\
\cline { 3 - 6 } & & Spot-2 & Yellowish & 0.87 \\
\hline
\end{tabular}

Table 2: Antioxidant activity of different plant extracts under study

\begin{tabular}{|l|l|c|}
\hline Name of the Plant & Solvent & Radical scavenging activity \\
\hline \multirow{3}{*}{ Sonchus asper } & n-hexane & 56.30 \\
\cline { 2 - 3 } & Chloroform & 57.59 \\
\cline { 2 - 3 } & Methanol & 59.87 \\
\hline \multirow{3}{*}{ Seseli diffusum } & n-hexane & 66.48 \\
\cline { 2 - 3 } & Chloroform & 61.47 \\
\cline { 2 - 3 } & Methanol & 65.12 \\
\hline
\end{tabular}

Table 3 Antimicrobial activities of Sonchus asper

\begin{tabular}{|c|c|c|c|c|c|c|}
\hline $\begin{array}{l}\text { Name of the } \\
\text { Plant }\end{array}$ & Test Agent & Concentration & $\begin{array}{l}\text { Micrococcus } \\
\text { sp. }\end{array}$ & $\begin{array}{l}\text { Staphylococcus } \\
\text { aureus }\end{array}$ & Shigella flexneri & Escherechia coli \\
\hline \multirow{13}{*}{$\begin{array}{l}\text { Sonchus } \\
\text { asper }\end{array}$} & Ciprofloxacin (RA) & $0.5 \mathrm{mg} / \mathrm{ml}$ & $30 \pm 0.816$ & $32 \pm 1.69$ & $28 \pm 0.8$ & $20 \pm 0.816$ \\
\hline & \multirow[t]{4}{*}{ Methanol extract } & $6 \mathrm{mg} / \mathrm{ml}$ & $23 \pm 1.69$ & $28 \pm 1.63$ & ---- & $10 \pm 0.81$ \\
\hline & & $3 \mathrm{mg} / \mathrm{ml}$ & $21 \pm 0.81$ & $27 \pm 1.63$ & ---- & $9 \pm 0.81$ \\
\hline & & $1.5 \mathrm{mg} / \mathrm{ml}$ & $18.33 \pm 1.24$ & $26 \pm 0.81$ & ---- & $8.33 \pm 1.24$ \\
\hline & & $0.75 \mathrm{mg} / \mathrm{ml}$ & $-\cdots$ & $24.6 \pm 1.69$ & $-\cdots$ & $\begin{array}{ll}---- \\
\end{array}$ \\
\hline & \multirow[t]{4}{*}{ n-hexane extract } & $6 \mathrm{mg} / \mathrm{ml}$ & $10 \pm 0.81$ & $10.33 \pm 0.471$ & $21.66 \pm 1.24$ & $10 \pm 0.81$ \\
\hline & & $3 \mathrm{mg} / \mathrm{ml}$ & $9.66 \pm 1.24$ & $9 \pm 0.81$ & $19.33 \pm 1.24$ & $9.66 \pm 1.24$ \\
\hline & & $1.5 \mathrm{mg} / \mathrm{ml}$ & $8.66 \pm 1.24$ & ---- & $18.66 \pm 1.24$ & $9 \pm 0.81$ \\
\hline & & $0.75 \mathrm{mg} / \mathrm{ml}$ & $-\cdots$ & ---- & $\begin{array}{ll}--- \\
\end{array}$ & $8 \pm 0.81$ \\
\hline & \multirow[t]{4}{*}{ Chloroform extract } & $6 \mathrm{mg} / \mathrm{ml}$ & $13.33 \pm 0.471$ & $9 \pm 0.81$ & $9.66 \pm 1.24$ & $12 \pm 0.816$ \\
\hline & & $3 \mathrm{mg} / \mathrm{ml}$ & $12 \pm 0.81$ & $10 \pm 0.81$ & $9 \pm 0.81$ & $11 \pm 0.81$ \\
\hline & & $1.5 \mathrm{mg} / \mathrm{ml}$ & $10 \pm 0.81$ & $\begin{array}{ll}--- \\
\end{array}$ & $9 \pm 0.81$ & $9 \pm 0.83$ \\
\hline & & $0.75 \mathrm{mg} / \mathrm{ml}$ & ---- & ---- & ---- & ---- \\
\hline
\end{tabular}

Result expressed as mean \pm S.D (n=3) (----) denotes no zone of inhibition.

Table 4. Antibacterial activity of Seseli diffusum

\begin{tabular}{|c|c|c|c|c|c|c|}
\hline $\begin{array}{l}\text { Name of } \\
\text { the Plant }\end{array}$ & Test Agent & Concentration & $\begin{array}{l}\text { Micrococcus } \\
\text { sp. }\end{array}$ & $\begin{array}{l}\text { Staphylococcus } \\
\text { aureus }\end{array}$ & $\begin{array}{l}\text { Shigella } \\
\text { flexneri }\end{array}$ & $\begin{array}{l}\text { Escherichia } \\
\text { coli }\end{array}$ \\
\hline \multirow[t]{13}{*}{$\begin{array}{l}\text { Seseli } \\
\text { diffusum }\end{array}$} & $\begin{array}{l}\text { Ciprofloxacin } \\
\text { (RA) }\end{array}$ & $0.5 \mathrm{mg} / \mathrm{ml}$ & $30 \pm 0.816$ & $32 \pm 1.69$ & $28 \pm 0.81$ & $20 \pm 0.816$ \\
\hline & \multirow[t]{4}{*}{ Methanol extract } & $6 \mathrm{mg} / \mathrm{ml}$ & $13 \pm 1.24$ & $\begin{array}{ll}--- \\
\end{array}$ & $18 \pm 1.29$ & $9 \pm 0.81$ \\
\hline & & $3 \mathrm{mg} / \mathrm{ml}$ & $13.33 \pm 1.24$ & $\begin{array}{ll}--- \\
\end{array}$ & $17 \pm 0.82$ & $9 \pm 0.83$ \\
\hline & & $1.5 \mathrm{mg} / \mathrm{ml}$ & $10.66 \pm 1.24$ & $\begin{array}{l}--- \\
\end{array}$ & $17 \pm 0.84$ & $9 \pm 0.74$ \\
\hline & & $0.75 \mathrm{mg} / \mathrm{ml}$ & $9 \pm 0.81$ & $\begin{array}{ll}--- \\
\end{array}$ & ---- & ---- \\
\hline & \multirow[t]{4}{*}{ n-hexane extract } & $6 \mathrm{mg} / \mathrm{ml}$ & $7.66 \pm 1.24$ & $12 \pm 0.80$ & $18 \pm 0.816$ & $8.33 \pm 1.24$ \\
\hline & & $3 \mathrm{mg} / \mathrm{ml}$ & $13 \pm 0.81$ & $12 \pm 0.80$ & $9 \pm 0.81$ & $11 \pm 0.81$ \\
\hline & & $1.5 \mathrm{mg} / \mathrm{ml}$ & $11 \pm 0.826$ & $\begin{array}{ll}--- \\
\end{array}$ & $9 \pm 0.81$ & $\begin{array}{ll}--- \\
\end{array}$ \\
\hline & & $0.75 \mathrm{mg} / \mathrm{ml}$ & $\begin{array}{l}--- \\
\end{array}$ & $\begin{array}{ll}--- \\
\end{array}$ & ---- & $\begin{array}{ll}--- \\
\end{array}$ \\
\hline & \multirow{4}{*}{$\begin{array}{l}\text { Chloroform } \\
\text { extract }\end{array}$} & $6 \mathrm{mg} / \mathrm{ml}$ & $19.33 \pm 0.471$ & $9 \pm 0.816$ & $17 \pm 0.816$ & $14.33 \pm 1.24$ \\
\hline & & $3 \mathrm{mg} / \mathrm{ml}$ & $18 \pm 0.81$ & $8.33 \pm 0.94$ & $16 \pm 1.63$ & $11.66 \pm 1.24$ \\
\hline & & $1.5 \mathrm{mg} / \mathrm{ml}$ & ---- & $9 \pm 0.816$ & $15.33 \pm 1.24$ & $13 \pm 0.816$ \\
\hline & & $0.75 \mathrm{mg} / \mathrm{ml}$ & $\begin{array}{ll}--- \\
\end{array}$ & $\begin{array}{ll}--- \\
\end{array}$ & $\begin{array}{ll}--- \\
\end{array}$ & $11.3 \pm 1.243$ \\
\hline
\end{tabular}

Result expressed as mean \pm S.D (n=3) (---) denotes no zone of inhibition.

Fig. 1 Antioxidant activity of Seseli diffusum 


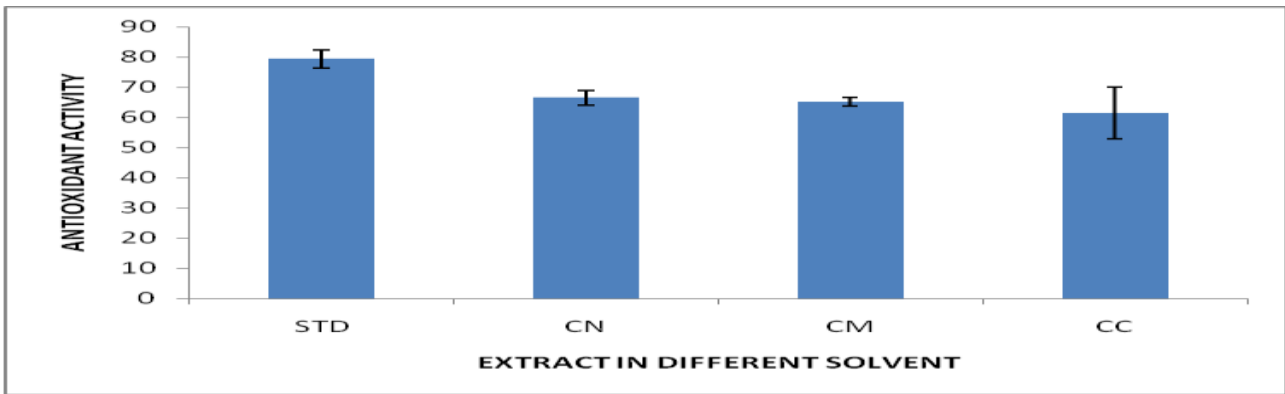

STD: standard, CN: n-hexane extract, CM : methanol extract, CC: chloroform extract

Fig: 2 Antioxidant activity of Sonchus asper

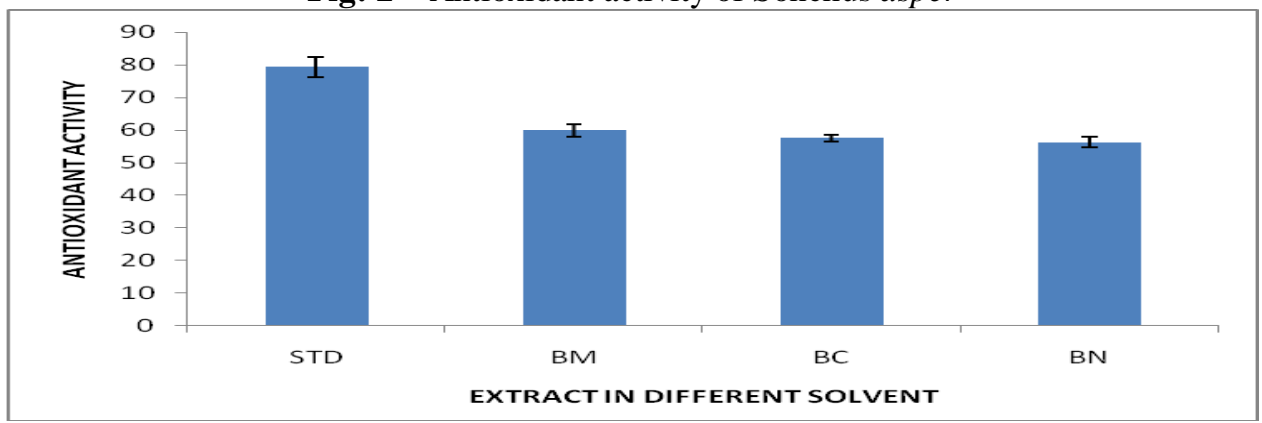

STD: standard, BM: methanol extract, BC: chloroform extract, BN: n-hexane extract

\section{Conclusion}

From the above study it can be concluded that both the plants have antimicrobial and antioxidant activities. It is evident that further studies on chemical analyses of two important medicinal plants studied under the present investigation may lead to the isolation of important bioactive molecules. The isolation of bioactive constituents of both the plant species and their structural elucidation can be done by using various other chromatographic techniques.

\section{Reference}

[1]. M. Bajpai, A. Pande, S K Tewari and D. Prakash, Phenolic contents and antioxidant activity of some food and medicinal plants. International Journal of Food Sciences and Nutrition, 56(4), 2005, 287-291.

[2]. R.A.A. Mothana and U. Lindequist. Antimicrobial activity of some medicinal plants of the island Soqotra. Journal of Ethnopharmacology 96, 2005, 177-181.

[3]. Wojdylo, J .Oszmianski and R. Czemerys, Antioxidant activity and phenolic compounds in 32 selected herbs, Food Chemistry, 105, 2007, 940-949.

[4]. J. Hutchinson., J. Colosi, and R.A. Lewin. The biology of Canadian weeds. 63. Sonchus asper L. Hill and S. oleraceus L. Canadian Journal of Plant Science 64, 1984, 731-744.

[5]. R.A. Khan, M.R. Khan, S. Sahreen, J. Bokhari. Antimicrobial and Phytotoxic screening of various fractions of Sonchus asper. Afr. J. Biotechnol, 9(25), 2010, 3883-3887.

[6]. Atta ur Rahman. Antistressor effect of Withania somnifera. Journal of Ethnopharmacology, 64, 1, 1991, 91-93 DOI, 10.1016/S0378-8741(98)00107-X

[7]. P.G. Kareru, G. M. Kenji, A N. Gachanja, J M. Keriko, G. Mungai, Traditional Medicines among the Embu and Mbeere Peoples of Kenya. Afr J Trad, CAM, 4(1), 2007, 75-86.

[8]. 10. G. Jan, M.A. Khan, F. Gul. Ethnomedicinal Plants used against Jaundice in Dir Kohistan Valleys (NWFP) Pakistan. Ethno. Leaflets, 13, 2009, 1029-1041.

[9]. A. M. Sammon. Protease Inhibitors and Carcinoma of the Esophagus. Cancer, 83, 1998, 405-408.

[10]. B. Thomson, IA .Shaw Comparison of Risk and Protective Factors for Colorectal Cancer in the Diet of New Zealand Maori and non Maori Asian Pacific J. Cancer Prevention, 3, 2002, 319-32.

[11]. H.O. Saxena, and M. Brahmam, The Flora of Orissa vol. 1-4, 1994-96, Orissa Forest Development Corporation, Bhubaneswar, Odisha. 